\title{
The cytotoxicity of resin composites cured with three light curing units at different curing distances
}

\author{
Gulfem Ergun ${ }^{1}$, Ferhan Egilmez ${ }^{1}$, Isil Cekic-Nagas ${ }^{2}$ \\ ${ }^{1}$ Department of Prosthodontics, Faculty of Dentistry, Gazi University, Ankara, Turkiye \\ ${ }^{2}$ School of Dental Technology, Hacettepe University, Ankara, Turkiye
}

Correspondence:

Suslu Sokak 14/9

Mebusevleri-Tandogan

Ankara / TURKIYE

ergungulfem@yahoo.com

Received: $13 / 03 / 2010$

Accepted: 26/08/2010

Ergun G, Egilmez F, Cekic-Nagas I. The cytotoxicity of resin composites cured with three light curing units at different curing distances. Med Oral Patol Oral Cir Bucal. 2011 Mar 1;16 (2):e252-9.

http://www.medicinaoral.com/medoralfree01/v16i2/medoralv16i2p252.pdf

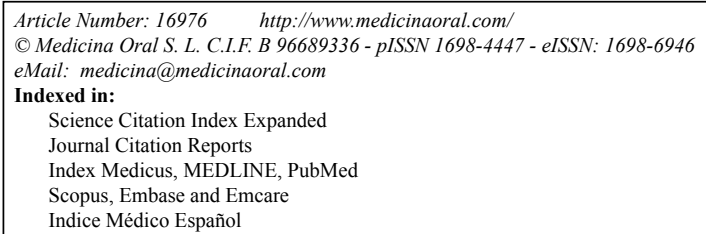

\begin{abstract}
Objective: The purpose of this study was to compare the effect of light curing distance on the cytotoxicity of five resin composites cured with three high-power light curing units.

Study design: Seven cylindrical discs of each material (Grandio ${ }^{\circledR}$, Voco; Filtek ${ }^{\text {TM }}$ Z250, 3M ESPE; Clearfil TM AP-X, Kuraray Co. Ltd.; Aelite TM LS, Bisco Inc. and Simile ${ }^{\circledR}$, Pentron) were cured. For curing, soft-up mode of quartz-tungsten-halogen, exponential mode of light emitting diode for $20 \mathrm{~s}$, and ramp-curing mode of plasma arc light curing units for $6 \mathrm{~s}$ were used. The curing tip distances were determined as 2 and $9 \mathrm{~mm}$ and controlled via the use of metal rings. After ageing the samples for 24 and 72 hours in Dulbecco's Modified Eagle Medium/Ham's F12 (DMEM/F12), cytotoxicity of the extracts to cultured fibroblasts (L 929) was measured by using MTT (tetrazolium salt 3-[4,5-dimethylthiazol-2-yl]-2,5-diphenyltetrazolium bromide) assay. The degree of cytotoxicity for each sample was determined according to the reference value represented by the cells in a pure culture medium. Statistical significance was determined using multifactorial analysis of variance.

Results: The type of resin composite $(p<0.05)$, light curing unit $(\mathrm{p}<0.05)$, curing tip distance $(\mathrm{p}<0.05)$ and evaluation period factor $(\mathrm{p}<0.05)$ had statistically significant cytotoxic effects on L-929 mouse fibroblast cells. However, when the tested materials polymerized at both distances $(2 \mathrm{~mm}$ and $9 \mathrm{~mm}$ ) in both evaluation periods (24h and $72 \mathrm{~h}$ ), there was no significant difference in the mean CSR\% values obtained when the quartz-tungsten-halogen, light emitting diode and plasma arc light curing units were used ( $\mathrm{p}=0.184, \mathrm{~F}=1.448)$.

Conclusions: The results of this study suggest that the light curing units and resin composites should be harmonized to one another and the curing distance between the tip of the light curing unit and the restoration surface should be as close as possible in order to achieve maximal biocompatibility.
\end{abstract}

Key words: Dental curing lights, cytotoxicity, composite resins. 


\section{Introduction}

Effective composite cure is a critical parameter, not only to ensure optimum physical properties of the cured restoration, but also to ensure that clinical problems do not arise as a result of the cytotoxicity of inadequately cured materials (1). If a light-activated resin composite does not receive sufficient energy at the correct wavelengths from the light curing unit (LCU). This could result in wear and greater breakdown of the restoration at the margins, decreased bond strength between the tooth and the restoration, reduced hardness, and greater cytotoxicity (2). Furthermore, this may lead to different releasing rates of unreacted toxic components from resin composites (3).

Nowadays, boosted versions of high intensity quartztungsten-halogen (QTH), plasma arc (PAC), light emitting diode (LED) LCUs that possess higher light intensity than conventional LCUs have been developed $(4,5)$. As it is known, high conversion is important for good mechanical properties and biocompatibility (6). In view of the great variety of LCUs and resin composite materials currently in use, the question is which combinations cause the least toxic effects. In addition, the effective light intensity available for the photoactivation of resin monomers is influenced by the distance between the light curing tip and the resin composite material. In other words, the intensity decreases with the square of the distance (7). Ideally, the LCU tip should be in direct contact with the surface of restoration. However, sometimes cavity design does not allow sufficient polymerization within this distance (8). As a consequence, the distance between the light tip and the restoration becomes a crucial parameter for cytotoxicity.

On these grounds, the aim of this study was to compare the effectiveness of high power QTH, LED, and PAC LCUs on cytotoxicity of five resin composites irradiated at two different curing distances. The null hypothesis was that the LCU type, curing distance and evaluation period affect the cytotoxicity of different resin composites.

\section{Materials and Methods \\ -Cells}

The cells used for the experiments were L-929 mouse fibroblasts (L-929 An2 HÜKÜK 95030802; Ankara Şap Enstitüsü, Ankara, Turkey). The cells were grown as monolayer cultures in T-25 flasks (Costar, Cambridge, MA, USA), subcultured three times a week at $37^{\circ} \mathrm{C}$ in an atmosphere of $5 \% \mathrm{CO}_{2}$ in air and $100 \%$ relative humidity and maintained at third passage. The culture medium was Dulbecco's modified Eagle medium (DMEM)/Ham's F12 nutrient mixture (1:1; Sigma, St Louis, MO, USA) supplemented with $10 \%$ (v/v) foetal bovine serum (FBS; Biochrom, Berlin, Germany) without antibiotics. Adherent cells at a logarithmic growth phase were controlled under an inverted tissue culture microscope (Olympus CK40, Japan) and detached with a mixture of $0.025 \%$ trypsin (Sigma) and $0.02 \%$ ethylenediaminetetraacetic acid (EDTA; Sigma), incubated for $2-5 \mathrm{~min}$ at $37^{\circ} \mathrm{C}$ and used for cell inoculation.

-Sample preparation

Five restorative resin composites $(2 \mathrm{~mm}$ in thickness and $6 \mathrm{~mm}$ in diameter) of shade A1 were used in this study ( $\mathrm{n}=84 /$ per group) (Table 1 ). Figure 1 shows the schematic illustration of sample preparation. The composite materials were placed into sterile circular polytetrafluoroethylene moulds. Polyethylene films were added on the top base of the composite materials and a $1 \mathrm{~mm}$ glass slide was placed on top of the mould to exclude excessive resin composite material and to eliminate air bubbles. Then the samples were irradiated top through the metal rings used to control irradiation distances ( $2 \mathrm{~mm}$ and $9 \mathrm{~mm}$ ) by soft-up mode of QTH LCU (Blue Swan Digital, Dentanet, Ankara, Turkey) for $20 \mathrm{~s}$, exponential mode of LED LCU (Elipar Freelight 2, 3M Espe, St. Paul, Minn, USA) for $20 \mathrm{~s}$ and ramp-curing mode of PAC LCU (PlasmaStar, SP-2000, Monitex, Taiwan) for $6 \mathrm{~s}$ under aseptic conditions at laminar flow (Holten, Class II, Denmark) (Table 2). All samples were prepared by the same operator.

The freshly prepared tested samples were placed immediately at the bottom of six well-plates (Costar, Cambridges, MA, USA). The samples were placed in DMEM/F12 with $10 \% \mathrm{FBS}$ and incubated at $37{ }^{\circ} \mathrm{C}$ in an atmosphere of $5 \% \mathrm{CO}_{2}$ in air without agitation for $24 \mathrm{~h}$ and $72 \mathrm{~h}$. After the incubation, the extracts were filtered through $0.22 \mu \mathrm{m}$ cellulose acetate filters (Millipore, Sigma, St. Louis, MO, USA) and then they were used to evaluate cytotoxicity.

-Cytotoxicity testing (MTT assay)

The L-929 cell suspension with DMEM/F12 with 10\% FBS and $1 \%$ antibiotic was prepared at a concentration of $3 \times 10^{4}$ cells $\mathrm{mL}^{-1}$ and inoculated onto 96-well cluster cell culture plates $(100 \mu \mathrm{L}$ per well). The multiwell plates were incubated at $37^{\circ} \mathrm{C}, 5 \% \mathrm{CO}_{2}$ in air for $24 \mathrm{~h}$. After $24 \mathrm{~h}$, the culture medium was removed from the wells and equal volumes $(100 \mu \mathrm{L})$ of the extracts were added into each well. In control wells, $100 \mu \mathrm{L}$ DMEM/ F12 with $10 \%$ FBS and $1 \%$ antibiotic was added. After the 24 and $72 \mathrm{~h}$ incubation periods, test extracts were removed. Following the removal of the test extracts, 100 $\mu \mathrm{L}$ per well DMEM/F12 with $10 \%$ FBS and $1 \%$ antibiotic and $12 \mu \mathrm{L}$ MTT (tetrazolium salt 3-[4,5-dimethylthiazol-2-yl]-2,5-diphenyltetrazolium bromide) were added to each well and incubated in a dark environment for $4 \mathrm{~h}$ at $37^{\circ} \mathrm{C}$. After incubation, 96 wells were checked for formazan crystals with inverted tissue culture microscope. MTT was aspirated and $100 \mu \mathrm{L}$ per well of isopropanol (Merck, Darmstadt, Germany) was added to each well. Subsequently, the absorbance at $570 \mathrm{~nm}$ 
Table 1. Resin composites used in this study.

\begin{tabular}{|c|c|c|c|c|c|c|}
\hline $\begin{array}{l}\text { Trade } \\
\text { Name }\end{array}$ & Code & Composition & Type & $\begin{array}{l}\text { Filler } \\
\text { load* }(\% \\
\text { by } \\
\text { weight }) \\
\end{array}$ & $\begin{array}{l}\text { Lot } \\
\text { Number }\end{array}$ & Manufacturer \\
\hline $\begin{array}{l}\text { Clearfil }^{\mathrm{TM}} \\
\text { AP-X }\end{array}$ & $\mathbf{A}$ & $\begin{array}{l}\text { Silanated barium } \\
\text { glass, Silanated } \\
\text { colloidal silica, } \\
\text { silanated silica, }{ }^{\mathrm{a}} \text { Bis- } \\
\text { GMA, }{ }^{\mathrm{b}} \text { TEGDMA, } \\
\text { dl-Camphorquinone }\end{array}$ & $\begin{array}{l}\text { Micro } \\
\text { hybrid }\end{array}$ & $85.5 \%$ & 454BA & $\begin{array}{l}\text { Kuraray } \\
\text { Medical INC. } \\
\text { Okayama, } \\
\text { Japan }\end{array}$ \\
\hline Simile ${ }^{\circledR}$ & B & $\begin{array}{l}{ }^{\mathrm{c}} \text { PCBis-GMA, }{ }^{\mathrm{a}} \text { Bis- } \\
\text { GMA, }{ }^{\mathrm{d} U D M A}, \\
{ }^{\mathrm{e}} \text { HDDMA, Silane } \\
\text { Treated Barium } \\
\text { Boro-alumino } \\
\text { Silicate Glass, Silane } \\
\text { Treated Nano- } \\
\text { particulated Silica, } \\
\text { Zirconium Silicate, } \\
\text { photoinitiator, } \\
\text { accelerator, } \\
\text { stabilizer, silane and } \\
\text { pigments }\end{array}$ & $\begin{array}{l}\text { Nano- } \\
\text { hybrid }\end{array}$ & $75 \%$ & 144063 & $\begin{array}{l}\text { Pentron } \\
\text { Clinical } \\
\text { Technologies, } \\
\text { LLC, } \\
\text { Wallingford, } \\
\text { U.S.A. }\end{array}$ \\
\hline $\begin{array}{l}\text { Grandio® } \\
\text { Caps }\end{array}$ & $\mathbf{C}$ & $\begin{array}{l}\text { Inorganic fillers, } \\
\text { a'Bis-GMA, } \\
{ }^{\mathrm{b}} \text { TEGDMA, }{ }^{\mathrm{f}} \mathrm{BHT}, \\
{ }^{\mathrm{d}} \text { UDMA, silicate }\end{array}$ & $\begin{array}{l}\text { Nano- } \\
\text { hybrid }\end{array}$ & $87 \%$ & 581501 & $\begin{array}{l}\text { VOCO } \\
\text { GmbH, } \\
\text { Cuxhaven, } \\
\text { Germany } \\
\end{array}$ \\
\hline $\begin{array}{l}\text { Filtek }^{\mathrm{TM}} \\
\text { Z250 }\end{array}$ & D & $\begin{array}{l}{ }^{\mathrm{a}} \text { BisGMA, } \\
{ }^{\mathrm{b}} \text { TEGDMA. } \\
{ }^{\mathrm{d}} \text { UDMA, }{ }^{\mathrm{g}} \text { BisEMA }\end{array}$ & $\begin{array}{l}\text { Micro } \\
\text { hybrid }\end{array}$ & $82 \%$ & 20051212 & $\begin{array}{l}\text { ESPE Dental- } \\
\text { Medizin, } \\
\text { Seefeld, } \\
\text { Germany }\end{array}$ \\
\hline $\begin{array}{l}\text { Aelite }^{\mathrm{TM}} \\
\text { Aesthetic } \\
\text { Enamel }\end{array}$ & $\mathbf{E}$ & $\begin{array}{l}{ }^{\mathrm{g}} \text { Bis-EMA, }{ }^{\mathrm{a}} \text { Bis- } \\
\text { GMA, Glass frit, } \\
\text { Amorphous Silica }\end{array}$ & $\begin{array}{l}\text { Nano- } \\
\text { hybrid }\end{array}$ & $73 \%$ & 0500005455 & $\begin{array}{l}\text { Bisco, Inc. } \\
\text { Schaumburg, } \\
\text { U.S.A. }\end{array}$ \\
\hline
\end{tabular}

*According to the manufacturer's instructions.

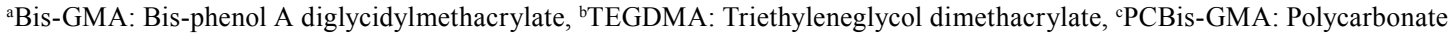
modified-Bis-GMA, ${ }^{d}$ UDMA: Urethane dimetacrylate, ${ }^{e}$ HDDMA: Hexanediol dimethacrylate, ${ }^{\mathrm{f}} \mathrm{BHT}$ : Butylated hydroxy toluene ${ }^{\mathrm{g} B i s-E M A: ~ e t h o x y l a t e d ~ b i s p h e n o l ~ A ~ d i m e t h a c r y l a t e . ~}$

A: Clearfil ${ }^{\mathrm{TM}}$ AP-X; B: Simile ${ }^{\circledR}$; C: Grandio ${ }^{\circledR}$ Caps; D: Filtek ${ }^{\mathrm{TM}}$ Z250; E: Aelite ${ }^{\mathrm{TM}}$ Aesthetic Enamel

was measured using a UV-visible spectrophotometer (LPB Pharmacia, Bromma, Sweden). Then, the viable cells were counted under a light microscope and calculated as a percentage of the control values at each evaluation period ( $24 \mathrm{~h}$ and $72 \mathrm{~h})$. Each cytotoxicity assay was evaluated three times for each experimental group. -Statistical analysis

Statistical analysis was performed by Statistical Package for Social Sciences (SPSS) 11.5 software (SPSS Inc., Chicago, IL, USA). Whether the data were normally distributed or not were determined by using Shapiro Wilk test. Homogeneity of variances was evaluated by
Levene test. Firstly, anscombe transformation was applied to data in order to transform the percentage of cytotoxicity variable in a Gaussian one. Data were expressed as mean \pm standard deviation. Multi factorial ANOVA taking such following factors as resin composites (5 levels), light curing units (3 levels), curing tip distances ( 2 levels) and evaluation periods (2 levels) was performed and post hoc Tukey test was applied for the evaluation of the data. A p value less than 0.05 was considered statistically significant. But, for all possible multiple comparison tests, Bonferroni Adjustment was applied to control Type I error. 
Table 2. Light curing units (LCUs) used in the study.

\begin{tabular}{|c|c|c|c|c|c|}
\hline LCUs & Trade Name & Manufacturer & Serial Number & $\begin{array}{c}\text { Light } \\
\text { Intensity }\end{array}$ & Polymerization Time* \\
\hline QTH & $\begin{array}{c}\text { Blue Swan } \\
\text { Digital }\end{array}$ & $\begin{array}{c}\text { Dentanet, } \\
\text { Ankara, } \\
\text { Turkey }\end{array}$ & $03-185$ & $\begin{array}{c}1000 \\
\mathrm{~mW} / \mathrm{cm}^{2}\end{array}$ & Soft-up mode: \\
\hline LED & $\begin{array}{c}\text { Elipar Freelight } \\
2\end{array}$ & $\begin{array}{c}3 \text { M Espe, St. } \\
\text { Paul, Minn, } \\
\text { USA }\end{array}$ & 939820014022 & $\begin{array}{c}1200 \\
\mathrm{~mW} / \mathrm{cm}^{2}\end{array}$ & $\begin{array}{c}\text { Exponential mode: } 20 \\
\mathrm{~s}\end{array}$ \\
\hline PAC & PlasmaStar, & $\begin{array}{c}\text { Monitex, } \\
\text { Taiwan }\end{array}$ & P0500206 & $\begin{array}{c}2250 \pm 50 \\
\mathrm{~mW} / \mathrm{cm}^{2}\end{array}$ & Ramp curing mode: $6 \mathrm{~s}$ \\
\hline
\end{tabular}

* According to the manufacturer

Table 3. The mean cell survival rates (CSR\%) and standard deviations of the tested materials.

\begin{tabular}{|c|c|c|c|c|c|c|}
\hline \multirow{3}{*}{$\begin{array}{c}\text { Tested } \\
\text { Materials }\end{array}$} & \multirow{3}{*}{$\begin{array}{c}\text { Light } \\
\text { Curing Unit } \\
\text { (LCU) }\end{array}$} & \multirow{3}{*}{$\begin{array}{c}\text { Evaluation } \\
\text { Period }\end{array}$} & \multicolumn{4}{|c|}{ Irradiation distance } \\
\hline & & & \multicolumn{2}{|c|}{$2 \mathrm{~mm}$} & \multicolumn{2}{|c|}{$9 \mathrm{~mm}$} \\
\hline & & & $\begin{array}{l}\text { CSR\% } \\
\text { Mean }\end{array}$ & $\begin{array}{c}\text { Std. } \\
\text { Deviation }\end{array}$ & $\begin{array}{c}\text { CSR\% } \\
\text { Mean } \\
\end{array}$ & $\begin{array}{c}\text { Std. } \\
\text { Deviation }\end{array}$ \\
\hline \multirow{6}{*}{$\mathbf{A}$} & \multirow{2}{*}{ LED } & $24 \mathrm{~h}$ & 18,78 & 0,22 & 18,03 & 0,43 \\
\hline & & $72 \mathrm{~h}$ & 17,73 & 0,45 & 17,47 & 0,23 \\
\hline & \multirow{2}{*}{ QTH } & $24 \mathrm{~h}$ & 18,77 & 0,31 & 18,23 & 0,14 \\
\hline & & $72 \mathrm{~h}$ & 16,98 & 0,12 & 17,79 & 0,34 \\
\hline & \multirow{2}{*}{ PL } & $24 \mathrm{~h}$ & 18,79 & 0,18 & 17,98 & 0,34 \\
\hline & & $72 \mathrm{~h}$ & 17,63 & 0,48 & 17,67 & 0,41 \\
\hline \multirow{6}{*}{ B } & \multirow{2}{*}{ LED } & $24 \mathrm{~h}$ & 18,99 & 0,19 & 19,05 & 0,09 \\
\hline & & $72 \mathrm{~h}$ & 18,95 & 0,25 & 18,74 & 0,15 \\
\hline & \multirow{2}{*}{ QTH } & $24 \mathrm{~h}$ & 19,01 & 0,36 & 19,25 & 0,18 \\
\hline & & $72 \mathrm{~h}$ & 18,97 & 0,21 & 18,62 & 0,12 \\
\hline & \multirow{2}{*}{ PL } & $24 \mathrm{~h}$ & 19,53 & 0,17 & 18,66 & 0,17 \\
\hline & & $72 \mathrm{~h}$ & 19,17 & 0,13 & 17,92 & 0,30 \\
\hline \multirow{6}{*}{$\mathbf{C}$} & \multirow{2}{*}{ LED } & $24 \mathrm{~h}$ & 18,75 & 0,22 & 19,13 & 0,09 \\
\hline & & $72 \mathrm{~h}$ & 19,64 & 0,25 & 19,48 & 0,08 \\
\hline & \multirow{2}{*}{ QTH } & $24 \mathrm{~h}$ & 19,27 & 0,19 & 19,82 & 0,15 \\
\hline & & $72 \mathrm{~h}$ & 19,68 & 0,33 & 19,71 & 0,26 \\
\hline & \multirow{2}{*}{ PL } & $24 \mathrm{~h}$ & 19,73 & 0,14 & 19,36 & 0,20 \\
\hline & & $72 \mathrm{~h}$ & 19,48 & 0,63 & 19,53 & 0,11 \\
\hline \multirow{6}{*}{ D } & \multirow{2}{*}{ LED } & $24 \mathrm{~h}$ & 17,36 & 1,28 & 16,49 & 0,23 \\
\hline & & $72 \mathrm{~h}$ & 17,70 & 0,32 & 17,86 & 0,25 \\
\hline & \multirow{2}{*}{ QTH } & $24 \mathrm{~h}$ & 17,17 & 0,98 & 16,98 & 0,75 \\
\hline & & $72 \mathrm{~h}$ & 17,50 & 0,53 & 17,77 & 0,54 \\
\hline & \multirow{2}{*}{ PL } & $24 \mathrm{~h}$ & 17,62 & 0,45 & 17,59 & 0,45 \\
\hline & & $72 \mathrm{~h}$ & 17,11 & 0,40 & 17,12 & 0,44 \\
\hline \multirow{6}{*}{$\mathbf{E}$} & \multirow{2}{*}{ LED } & $24 \mathrm{~h}$ & 17,00 & 0,12 & 16,15 & 0,20 \\
\hline & & $72 \mathrm{~h}$ & 15,34 & 0,14 & 15,16 & 0,13 \\
\hline & \multirow{2}{*}{ QTH } & $24 \mathrm{~h}$ & 17,11 & 0,22 & 16,91 & 0,28 \\
\hline & & $72 \mathrm{~h}$ & 16,48 & 0,20 & 15,95 & 0,23 \\
\hline & \multirow{2}{*}{ PL } & $24 \mathrm{~h}$ & 15,71 & 0,20 & 14,79 & 0,27 \\
\hline & & $72 \mathrm{~h}$ & 14,05 & 0,21 & 13,78 & 0,15 \\
\hline
\end{tabular}

A: Clearfil ${ }^{\mathrm{TM}}$ AP-X; B: Simile ${ }^{\circledR} ;$ C: Grandio ${ }^{\circledR}$ Caps; D: Filtek ${ }^{\mathrm{TM}}$ Z250; E: Aelite ${ }^{\mathrm{TM}}$ Aesthetic Enamel 


\section{Results}

The cell numbers of all freshly prepared tested materials decreased compared to the control group (culture without sample) (Table 3).

Statistical analysis showed that there was a significant difference amongst the tested materials $(p<0.05$, $\mathrm{F}=593.606$ ). While the test material $\mathrm{C}$ exhibited the highest mean cell survival rates (CSR\%) (19.465 \pm 0.60$)$, $\mathrm{E}$ had the lowest mean CSR\% (15.702 \pm 0.60$)$ values. When the overall mean CSR\% values were evaluated, the test materials were ranked as $\mathrm{C}>\mathrm{B}>\mathrm{A}>\mathrm{D}>\mathrm{E}$.

Also, there were statistically significant differences for the number of surviving cells in the different LCUs $(\mathrm{p}<0.05, \mathrm{~F}=22.102)$. While the QTH LCU exhibited the highest mean CSR\% (18.098 \pm 0.47$)$, the LED LCU $17.891 \pm 0.47$ and the PAC LCU showed the lowest mean CSR\% (17.660 \pm 0.47$)$. When the overall mean CSR\% values were evaluated, the LCUs were ranked as QTH $>$ LED $>$ PAC.

The differences between the CSR\% values were also significant for the curing distances $(2 \mathrm{~mm}$ and $9 \mathrm{~mm}$ ) $(\mathrm{p}<0.05, \mathrm{~F}=18.901)$. In addition, the mean $\mathrm{CSR} \%$ values of the tested materials observed at different evaluation periods $(24 \mathrm{~h}$ and $72 \mathrm{~h}$ ) were statistically different $(p<0.05, F=46.963)$. In terms of overall mean CSR\% of $2 \mathrm{~mm}$ results were higher than the $9 \mathrm{~mm}$ results $(18.00 \pm 0.038,17.66 \pm 0.038$, respectively) and the $24 \mathrm{~h}$ results were higher than the $72 \mathrm{~h}$ results $(18.067 \pm 0.038$, $17.699 \pm 0.038$, respectively).

When the two factor interaction between the curing tip distances and LCUs was evaluated, it was shown that

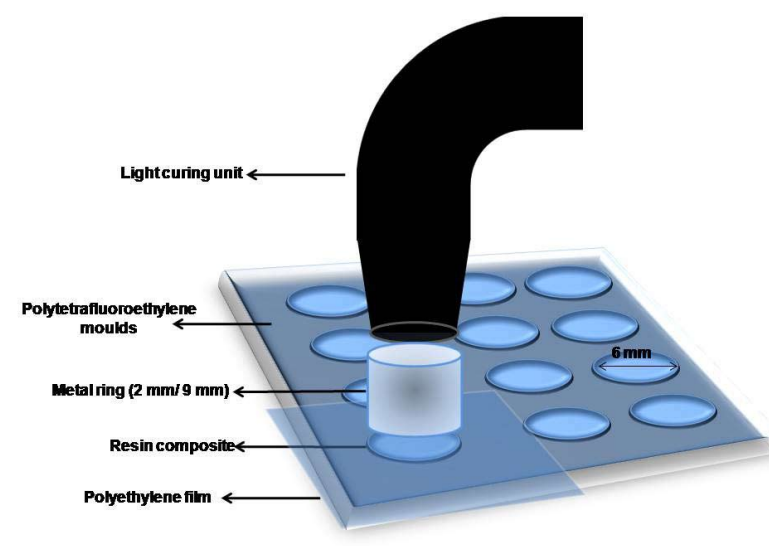

Fig. 1. Schematic illustration of sample preparation.

$2 \mathrm{~mm}$ and $9 \mathrm{~mm}$ curing distances for all LCUs had similar effect on the CSR\% values ( $\mathrm{p}=0.846, \mathrm{~F}=0.168$, $\mathrm{p}=0.239, \mathrm{~F}=1.457$, respectively). At the same time, when the QTH, LED and PAC LCUs were used at both curing distances $(2 \mathrm{~mm}$ and $9 \mathrm{~mm}$ ) overall mean CSR\% values were resulted statistically similar $(\mathrm{p}=0,976, \mathrm{t}=-0.03$ for QTH; $\mathrm{p}=0.439, \mathrm{t}=0.78$ for LED and $\mathrm{p}=0.35, \mathrm{t}=0.943$ for PAC LCU).

According to the ANOVA, there was no significant three-factor interaction amongst the tested materials, LCUs and curing distances $(\mathrm{p}=0,099, \mathrm{~F}=1.727)$. Additionally, data of all the tested materials for both cur-

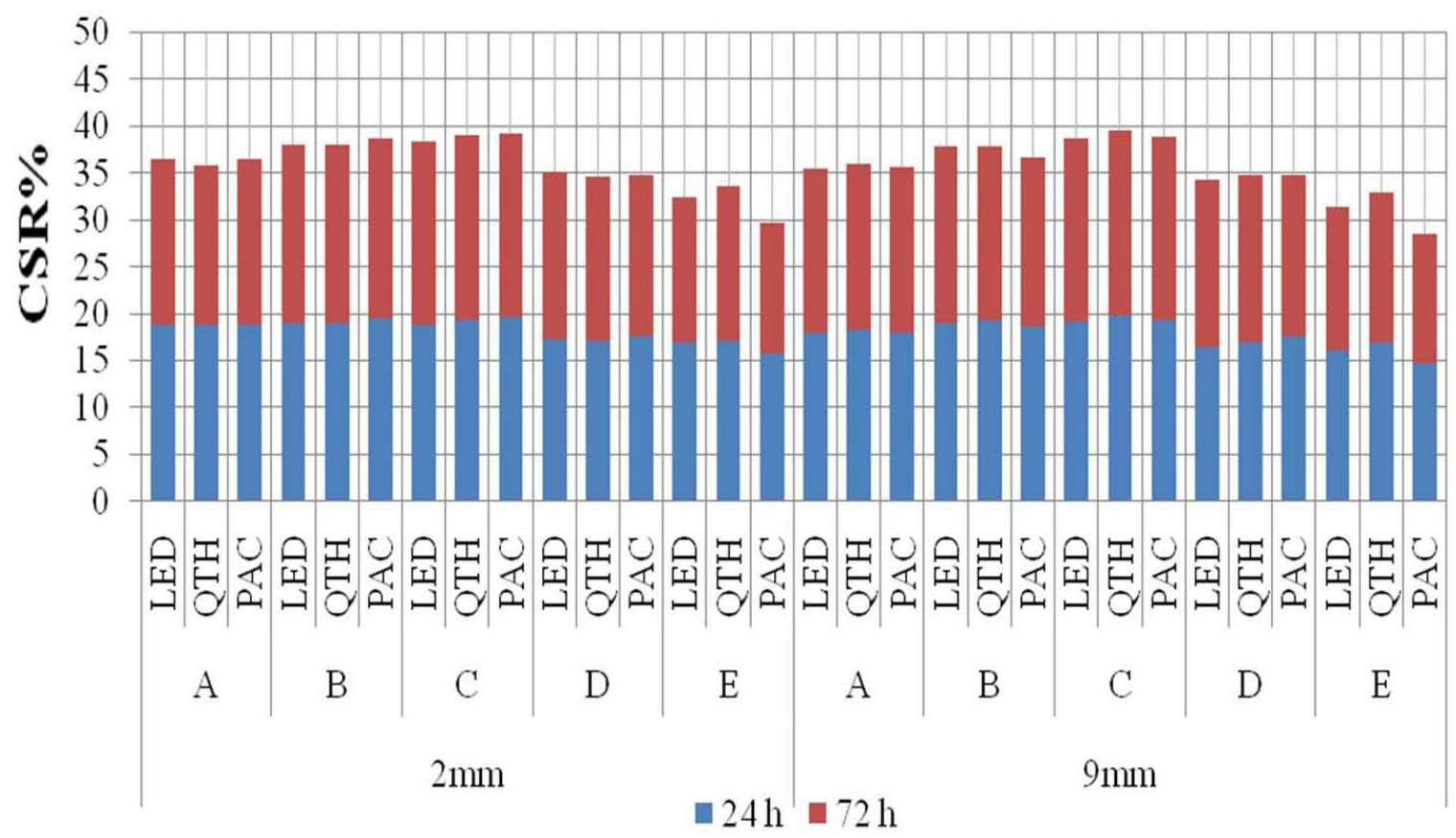

Fig. 2. The distribution of CSR\% values at different curing distances in each resin composite. CSR\% values were expressed as a percentage of control values (cultures without samples). Bars show the mean of three independent experiments. 
ing distances were combined, the overall mean CSR\% values were statistically similar between the LCUs at $24 \mathrm{~h}$ and $72 \mathrm{~h}$ evaluation periods $(\mathrm{p}=0.184, \mathrm{~F}=1.448)$. However a significant difference was found when the interaction among the tested materials, the LCUs and the evaluation periods for both curing distances $(2 \mathrm{~mm}$ and $9 \mathrm{~mm}$ ) was considered $(\mathrm{p}<0.033, \mathrm{~F}=2.892)$. At the 24h evaluation period QTH and PAC LCUs were able to polymerize test material $\mathrm{C}$ better than the LED LCU $(\mathrm{p}<0.008, \mathrm{~F}=8.832)$. On the contrary, at the both $24 \mathrm{~h}$ and $72 \mathrm{~h}$ evaluation periods, QTH and LED LCUs were able to polymerize test material $\mathrm{E}$ better than the PAC LCU $(\mathrm{p}<0.008, \mathrm{~F}=25.313, \mathrm{p}<0.008, \mathrm{~F}=125.972$, respectively). For other tested materials similar results were obtained when the QTH, LED and PAC LCUs were used for both curing distances $(2 \mathrm{~mm}$ and $9 \mathrm{~mm})$ at both $24 \mathrm{~h}$ and $72 \mathrm{~h}$ evaluation periods $(\mathrm{p}>0.008)$.

When the tested materials polymerized at both distances $(2 \mathrm{~mm}$ and $9 \mathrm{~mm})$ in both evaluation periods (24h and 72h), there was no significant difference in the mean CSR\% values obtained when the QTH, LED and PAC LCUs were used ( $p=0.184, F=1.448$ ). So there was no significant four factor interaction among the tested materials, the LCUs, curing distances and evaluation periods. The mean $\mathrm{CSR} \%$ and standard deviations of the tested materials were given in table 2 .

Figure 2 demonstrates the distribution of $\mathrm{CSR} \%$ of resin composites polymerized with LCUs at two irradiation distances in the evaluation periods.

\section{Discussion}

In the present study, the cytotoxic effect of five different resin composites cured with different LCUs at two curing distances were investigated with MTT assay at different evaluation periods (24h-72h). The assay used in this study was MTT (3-(4,5-dimethylthiazol-2-yl)2,5-diphenyl tetrazolium bromide), which is a widely used functional assay for biocompatibility evaluation, because of its reliability and sensitivity (9-11).

An adequate degree of conversion is necessary to improve the biocompatibility of composite materials used in restorative dentistry (9). A previous study by Caughman et al. (12) evaluated the correlation between cytotoxicity, filler loading and curing time of dental composites and concluded that when the percentage of monomer conversion increased, the cellular toxicity decreased. It has been reported that the filler content, filler size, and the distribution of the filler particles affect the properties of the resin composites. Thus, increasing the filler content and reducing the average filler size has been one approach in producing resin composites with excellent material properties and a good clinical performance (13). In addition, the nanofilled resin was launched in the market with the intention of offering enhanced curing depth (14). A study by Söderholm et al. (15) indicated that highly filled materials used for indirect resin restorations should exhibit less cytotoxicity because of their lower leachable resin content. In the light of all these information, in the present study, the material $\mathrm{C}$, with the highest filler content by weight (87\%), showed the highest CSR\% values of all the tested materials. The high filler load might have reduced the amount of resin available for dissolution. Moreover, this flowable universal nano-hybrid composite has lower viscosity facilitating molecular mobility and higher degree of monomer conversion. Lower viscosity results in greater DC\% increasing the mobility of molecules (16). Additionally, its silicon-dioxide nano-particles are designed to covalently bond to polymeric resin, increasing the conversion rate of the material $\mathrm{C}$, though reducing the possible releasing of toxic compounds. As for the comparison of CSR $\%$ values of the resin composites in the present study, the materials $\mathrm{B}$ and $\mathrm{C}$, nano-hybrid composites, exhibited higher CSR\% values than A and D microhybrid composites (Table 3). Despite being a nanofilled composite, the material $\mathrm{E}$ did not achieve the $\mathrm{CSR} \%$ values that other nanofiller composites did. This could be related with its lower filler content by weight (73\%, Table 1).

Both resin content and percentage of monomer conversion of dental materials were considered as potential causes of cytotoxicity (12). Methacrylate-based resin monomers released from resin composites, such as bisphenol A diglycidylmethacrylate (Bis-GMA), triethyleneglycol dimethacrylate (TEGDMA), urethane dimethacrylate (UDMA), have been shown to be cytotoxic in sufficient concentrations (17-19). A previous study by Hanks et al. (20) demonstrated cytotoxic effects of some resin components on DNA and protein synthesis on 3T3 fibroblasts and found ethoxylated bisphenol-A-dimethacrylate (Bis-EMA) as the most toxic, then UDMA and Bis-GMA; TEGDMA as slightly less toxic. This was in agreement with the current study in that, materials $\mathrm{D}$ and $\mathrm{E}$, which consist of Bis-EMA agent, showed the lowest CSR\% values, as this agent might be the most toxic one among the other dimethacrylates, as was demonstrated in the previously mentioned study (20).

In the present study, a high-intensity LED LCU has exposure time options as follows: 5, 10, 15 and 20s according to the manufacturer's instructions. Because of the high light intensity $\left(1200 \mathrm{~mW} / \mathrm{cm}^{2}\right)$ of this LCU, these time periods corresponds to the time periods $(10,20$, 30 and $40 \mathrm{~s}$ ) of conventional light curing unit that has light intensity of $600-800 \mathrm{~mW} / \mathrm{cm}^{2}$ for halogen technology or $300-400 \mathrm{~mW} / \mathrm{cm}^{2}$ light intensity for LED. Thus, the normal exposure times for conventional units can be cut in half without compromising curing performance. Similarly, according to the manufacturer's instructions of PAC LCU that has been used in this study, this LCU can produce four times as much of light intensity as the 
conventional LCU. Thereby, the curing time could be shortened to as much as $1 / 4$ of the curing time of the conventional halogen lamp. Moreover, due to high power capacity of LCUs used in the present study, resin materials were cured with high intensity QTH (soft-up mode) for $20 \mathrm{~s}$, with LED (exponential mode) for $20 \mathrm{~s}$, with ramp-curing mode of PAC for $6 \mathrm{~s}$.

In the current study, when the CSR\% values of the tested materials were considered, it was observed that the composite resins cured with QTH, LED and PAC LCUs showed different cytotoxicity values. It was demonstrated that, the QTH LCU resulted in the highest value in the number of surviving cells, while the PAC LCU had the lowest value. Moreover, based on the results of our study, when the QTH, LED and PAC LCUs were used for the polymerization of composites, the CSR\% values of materials $\mathrm{A}, \mathrm{B}, \mathrm{C}$ and $\mathrm{D}$ were found similar. However, the QTH and LED LCUs polymerize material $\mathrm{E}$ better than the PAC LCU $(\mathrm{p}<0.01, \mathrm{~F}=25,671)$. Therefore, according to the results, the LCU that gave good results for one composite material did not exhibit the same performance for another composite material. This could indicate the presence of cytotoxic monomers, which are inactivated by their conversion during the light curing process with different LCUs. Furthermore, the results revealed that there might be several possible reasons for different effects of composite resins or LCUs on their cytotoxicity such as the light transmission characteristics, the released energy during the curing of the resin composites and the amount as well as the type of released toxic substances from uncured resin composites. For this reason, in this study, it is not possible to grade the performances of the LCUs clinically. Although higher energy density leads to higher degree of conversion (1), a study by Knezevic et al. (21) reported that higher energy density also causes temperature rise. In literature, PAC LCUs, which have high energy densities, are often discussed as an alternative to high-power QTH and LED LCUs $(4,22)$. However, in the present study, resin composites cured with PAC LCU showed similar to or lower mean CSR\% values than QTH and LED LCUs except material E. The special spectrum of this lamp, which has very high light intensities $\left(2250 \pm 50 \mathrm{~mW} / \mathrm{cm}^{2}\right)$ at certain wavelengths, might have caused this outcome.

The distance between the tip of LCU and resin composite directly affects light intensity on the resin surface (7). Moreover, distances of more than $8 \mathrm{~mm}$ between LCU and the cavity have been demonstrated (23). To represent the clinical situations, the curing tip distances of $2 \mathrm{~mm}$ and $9 \mathrm{~mm}$ were used in the present study and controlled via the use of metal rings. Previous studies investigated the influence of curing tip distances on the microhardness of resin composites and concluded that as the curing tip distance increases, the hardness de- creases $(7,24)$. These results are in line with the results of the present study demonstrating the negative effects of the curing tip distance on cytotoxicity of resin composites. In the current study, in terms of overall mean CSR\% of $2 \mathrm{~mm}$ results were higher than the $9 \mathrm{~mm}$ results $(18.00 \pm 0.038,17.66 \pm 0.038$, respectively). According to the statistical analysis, there was a statistically significant difference among the curing distances, necessitating acceptance of the null hypothesis. The polymerization by LCUs at a distance of $2 \mathrm{~mm}$ had always higher CSR\% values in all tested materials.

LCUs with higher light intensities have great potential for use in restorative procedures. Decreasing the total cure time may be beneficial for the clinician and the patient. It was reported previously that, higher degree of conversion of the resin containing polymeric materials could be obtained by using the LCUs in high power modes (25). It was considered that, in the present study, high power modes of the LCUs might be able to achieve similar CSR\% values in the short curing times even at two different curing distances. What is more, there was a difference between the two evaluation periods on the cytotoxicity of the tested materials. Furthermore, the evaluation periods ( $24 \mathrm{~h}$ and $72 \mathrm{~h}$ ) had a statistically significant effect on the cytotoxicity of the resin composites cured with different LCUs. According to the results of the present study, the cytotoxicity of resin composites was LCU and time dependent, we are led to accept the null hypothesis. At the $24 \mathrm{~h}$ evaluation period QTH and PAC LCUs were able to polymerize test material C better than the LED LCU $(\mathrm{p}<0.008, \mathrm{~F}=8.832)$. On the contrary, at both $24 \mathrm{~h}$ and $72 \mathrm{~h}$ evaluation periods, QTH and LED LCUs were able to polymerize test material $\mathrm{E}$ better than the PAC LCU ( $p<0.008, F=25.313, p<0.008$, $\mathrm{F}=125.972$, respectively). In respect to the $\mathrm{CSR} \%$ values of material A irradiated from a distance at $2 \mathrm{~mm}$, it was found more cytotoxic at $72 \mathrm{~h}$ than at $24 \mathrm{~h}$ evaluation period. Also when the material $\mathrm{B}$ cured at a distance of $9 \mathrm{~mm}$ at $72 \mathrm{~h}$, it was found to be more toxic than at $24 \mathrm{~h}$ evaluation period. Furthermore, when the test materials A and E were cured with all the three LCUs, the $\mathrm{CSR} \%$ results of the $24 \mathrm{~h}$ evaluation period were statistically higher than the $72 \mathrm{~h}$ results. A previous study by Ferracane and Condon (26) reported that the most toxic effects from resin composites occur during the first $24 \mathrm{~h}$ of testing. As opposed to these authors (26) the present study showed that the release of the unreacted toxic components from the composite materials continues and that there is no one ideal LCU for all the composite materials.

As the results have indicated, the resin composites cured with the three LCUs at two curing distances may cause harmful effects to the biological tissues. The dentist should always check whether the curing light and irradiation distance used are adequate to polymerize 
the particular brand of resin used or not. Nevertheless, from a clinical point of view, LCUs and resin composites should be harmonized to one another for achieving maximal biocompatibility.

\section{Conclusions}

Within the limitations of this in-vitro study, the following conclusions could be drawn:

1. The cytotoxic effects in the cell culture showed dependence on the type of resin composite. While significantly highest cytotoxicity was obtained in the tested material E, the lowest cytotoxicity was obtained in the material C. The cytotoxicity of the tested materials can be rank based on the $\mathrm{CSR} \%$ indicated by $\mathrm{C}>\mathrm{B}>\mathrm{A}>$ $\mathrm{D}>\mathrm{E}$.

2. The distance between the tip of the LCU and the restoration surface should be as close as possible. When this approximation is not possible, the more suitable LCU with the restorative material should be selected according to clinical situation.

\section{References References with links to Crossref-DOI}

1. Knezevic A, Zeljezic D, Kopjar N, Tarle Z. Cytotoxicity of composite materials polymerized with LED curing units. Oper Dent. 2008;33:23-30.

2. Aguiar FH, Braceiro A, Lima DA, Ambrosano GM, Lovadino JR. Effect of light curing modes and light curing time on the microhardness of a hybrid composite resin. J Contemp Dent Pract. 2007;8:1-8. 3. Sigusch BW, Völpel A, Braun I, Uhl A, Jandt KD. Influence of different light curing units on the cytotoxicity of various dental composites. Dent Mater. 2007;23:1342-8.

4. Cekic I, Ergun G, Lassila LV, Vallittu PK. Ceramic-dentin bonding: effect of adhesive systems and light-curing units. J Adhes Dent. 2007;9:17-23.

5. Ceballos L, Fuentes MV, Tafalla H, Martínez A, Flores J, Rodríguez J. Curing effectiveness of resin composites at different exposure times using LED and halogen units. Med Oral Patol Oral Cir Bucal. 2009;14:E51-6.

6. Tseng WY, Huang CH, Chen RS, Lee MS, Chen YJ, Rueggeberg FA, et al. Monomer conversion and cytotoxicity of dental composites irradiated with different modes of photoactivated curing. J Biomed Mater Res B Appl Biomater. 2007;83:85-90.

7. Rode KM, Kawano Y, Turbino ML. Evaluation of curing light distance on resin composite microhardness and polymerization. Oper Dent. 2007;32:571-8.

8. Pires JA, Cvitko E, Denehy GE, Swift EJ Jr. Effects of curing tip distance on light intensity and composite resin microhardness. Quintessence Int. 1993;24:517-21.

9. Cao T, Saw TY, Heng BC, Liu H, Yap AU, Ng ML. Comparison of different test models for the assessment of cytotoxicity of composite resins. J Appl Toxicol. 2005;25:101-8.

10. Taoufik K, Mavrogonatou E, Eliades T, Papagiannoulis L, Eliades G, Kletsas D. Effect of blue light on the proliferation of human gingival fibroblasts. Dent Mater. 2008;24:895-900.

11. Ergün G, Eğilmez F, Uçtaşli MB, Yilmaz S. Effect of light curing type on cytotoxicity of dentine-bonding agents. Int Endod J. 2007;40:216-23.

12. Caughman WF, Caughman GB, Shiflett RA, Rueggeberg F, Schuster GS. Correlation of cytotoxicity, filler loading and curing time of dental composites. Biomaterials. 1991;12:737-40.

13. Manhart J, Kunzelmann KH, Chen HY, Hickel R. Mechanical properties of new composite restorative materials. J Biomed Mater Res. 2000;53:353-61.

14. Thomé T, Steagall W Jr, Tachibana A, Braga SR, Turbino ML. Influence of the distance of the curing light source and composite shade on hardness of two composites. J Appl Oral Sci. 2007;15:486-91.

15. Söderholm KJ, Mukherjee R, Longmate J. Filler leachability of composites stored in distilled water or artificial saliva. J Dent Res. 1996;75:1692-9.

16. Cekic-Nagas I, Ergun G, Vallittu PK, Lassila LV. Influence of polymerization mode on degree of conversion and micropush-out bond strength of resin core systems using different adhesive systems. Dent Mater J. 2008;27:376-85.

17. Yoshii E. Cytotoxic effects of acrylates and methacrylates: relationships of monomer structures and cytotoxicity. J Biomed Mater Res. 1997;37:517-24.

18. Harorli OT, Bayindir YZ, Altunkaynak Z, Tatar A. Cytotoxic effects of TEGDMA on THP-1 cells in vitro. Med Oral Patol Oral Cir Bucal. 2009;14:e489-93.

19. Ergün G, Mutlu-Sagesen L, Karaoglu T, Dogan A. Cytotoxicity of provisional crown and bridge restoration materials: an in vitro study. J Oral Sci. 2001;43:123-8.

20. Hanks CT, Strawn SE, Wataha JC, Craig RG. Cytotoxic effects of resin components on cultured mammalian fibroblasts. J Dent Res. 1991;70:1450-5.

21. Knezević A, Tarle Z, Meniga A, Sutalo J, Pichler G, Ristić M. Degree of conversion and temperature rise during polymerization of composite resin samples with blue diodes. J Oral Rehabil. 2001;28:586-91.

22. Jung H, Friedl KH, Hiller KA, Furch H, Bernhart S, Schmalz G. Polymerization efficiency of different photocuring units through ceramic discs. Oper Dent. 2006;31:68-77.

23. Hansen EK, Asmussen E. Visible-light curing units: correlation between depth of cure and distance between exit window and resin surface. Acta Odontol Scand. 1997;55:162-6.

24. Aguiar FH, Lazzari CR, Lima DA, Ambrosano GM, Lovadino JR. Effect of light curing tip distance and resin shade on microhardness of a hybrid resin composite. Braz Oral Res. 2005;19:302-6.

25. Usümez S, Büyükyilmaz T, Karaman AI, Gündüz B. Degree of conversion of two lingual retainer adhesives cured with different light sources. Eur J Orthod. 2005;27:173-9.

26. Ferracane JL, Condon JR. Rate of elution of leachable components from composite. Dent Mater. 1990;6:282-7.

\section{Acknowledgments}

This study was financed by the Unit of Scientific Research Projects fund of Gazi University. 